\title{
SENI DAN TEKNOLOGI: Tantangan dan Peluang dalam Dunia Tari
}

\author{
Een Herdiani ${ }^{1}$ \\ ${ }^{1}$ ISBI Bandung \\ Email: een_herdiani@isbi.ac.id \\ disajikan dalam Webinar "Seni, Teknologi, dan Masyarakat \#5 2020. \\ ISI Surakarta tahun 2020
}

\begin{abstract}
RINGKASAN
Teknologi dan seni kini menjadi bidikan yang seksi oleh para kreator untuk melahirkan karya-karya dengan media baru. Termasuk dalam bidang tari. Miroto sebagai salah satu koreografer ternama di Indonesia mempelopori penggunaan teknologi dalam karya-karyanya. Kecanggihan teknologi dimanfaatkannya untuk memunculkan kebaruan dalam tari terutama dalam gerak dan tempat pertunjukan. Eksperimennya dilakukan bertahun-tahun hingga kebaruan dan orisinalitasnya terjaga. Kreator lain berlatar belakang rupa dan teknologi yaitu Harry Nuriman yang mengawinkan tari dan teknologi untuk mendigitalisasikan gerak menggunakan metode dan media Motion Capture. Dua model karya ini diangkat dengan tujuan menunjukkan dua model yang berbeda dengan fokus yang sama mengenai tari. Hal ini sebagai pemodelan untuk menangkap peluang dan menjawab tantangan dalam pemanfaatan teknologi pada bidang tari.
\end{abstract}

\section{PENDAHULUAN}

Teknologi dipandang sebagai perpanjangan tangan dari sains-modern yang dianggap selalu berurusan dengan kepastian rasional dan serba keterukuran logika positivisme. Sementara seni pada umumnya dilihat sebagai praksis filosofis yang identik dengan ketidakpastian, penafsiran personal, dan subjektivitas. Di samping itu, teknologi juga dipandang sebagai perwujudan nyata dari cita-cita kemajuan peradaban modern secara konkrit yang berdampak pada kehidupan manusia. Sementara seni dilihat sebagai aktuaisasi pengalaman batin, intuisi, dunia prareflektif manusia dan khasanah maknawi yang tak terjamah. Tampak sekali ada pertentangan sudut pandang dari masyarakat umum di antara keduanya. Dalam perjalanannya sejarahnya kehadiran para kreator yang mengawinkan seni dengan teknologi semakin semarak. Perkembangan arus informasi dan makin gemerlapnya kemajuan teknologi menjadi peluang dalam pengembangan bidang seni termasuk inovasi untuk bidang tari.

Teknologi yang maju dengan pesat menjadi peluang besar untuk pengembangan seni tari dalam era disrupsi ini. Di luar negeri kemajuan teknologi ini sudah direspon lebih dulu. Namun di Indonesia pun tidak kalah muncul pelopor-pelopor penggarapan tari yang merespon kecanggihan teknologi dalam mewujudkan karya-karyanya.

Fasilitas internet digunakan Miroto dalam kebaruan karyanya dan model hologram serta teleholografis sebagai medianya. Sementara Harry Nuriman mengunakan perangkat teknologi dengan menggunakann media Motion Capture (MOCAP) untuk menditeksi dan mendigitalisasikan gerak tari. Keduanya mengambil objek yang sama yaitu tari dengan menggunakan perkembangan teknologi tetapi tujuannya berbeda. Di luar itu peluang lain yang bisa digunakan untuk mengawinkan tari dan teknologi adalah media Virtual Reality (VR), dan Augmented Reality (AR). Peluang untuk itu masih terbuka lebar. Namun yang akan dibahas dalam makalah ini adalah karya Miroto dan Harry Nuriman. 


\section{PEMBAHASAN}

Karya Miroto dan Harry Nuriman menjadi dua model pengembangan tari dengan menggunakan kecanggihan teknologi. Keduanya bereksperimen untuk menemukan kebaruan-kebaruan yang bisa digali dari keduanya.

\section{KARYA-KARYA MIROTO YANG BERBASIS TEKNOLOGI}

Gagasan memadukan tari dan teknologi semakin kuat ketika Miroto bergabung dengan Garin Nugroho dalam pembuatan film musikal "OPERA JAWA". Kolaborasi yang dilakukan pertama ini bagi Mirono menjadi penting dalam sejarah seni pertunjukan Indonesia (Supriyanto, dkk.: 2014). Semangat Miroto tak pernah padam untuk terus berkarya. Pada tahun 2014 la melakukan eksperimen yang mengejutkan dunia tari. Miroto memanfaatkan internet, digital dan papper gost dalam mengembangkan karya-karyanya. Hal ini menjadi catatan sejarah penting dalam perkembangan seni tari di Indonesia. la mengusung teknologi hologram yang pertama di dunia tari internasional (Radar, 2014). Miroto menggarap "Tari Realitas Teleholografis" (2014). Dalam teknik ini Miroto menghadirkan penari yang berbeda tempat, bahkan berbeda negara. Secara 3D Mereka yang terhubung secara virtual itu seolah-olah hadir di panggung dalam pertunjukan tersebut. Banyak orang penasaran dan bertanya tentang media yang digunakannya. Tidak berhenti di situ, karya-karya lain bermunculan dengan menggunakan media tersebut. Diantaranya adalah "Simulakra" (2015 dan 2017) dan "Body in Between" (2016). Miroto menghadirkan dunia nyata dengan dunia maya dalam sebuah panggung pertunjukan. Dalam karyanya tubuh menjadi hiperatif dalam dunia simulasi yang membaur antara nyata dan maya. Roh baru internet ini mengontrol tubuh sekaligus menjadi media baru dalam berinteraksi dengan dunia masa kini di jaman cyberspace. Tontonan tersebut memberikan pengalaman visual diantara seni pertunjukan dan film. Sebuah format pertunjukan hibrida yang membaurkan ruang nyata dan maya. Ini menjadi penanda jaman cyberspace (Kryoga, 2015). Sebuah ulasan menarik dalam media masa.

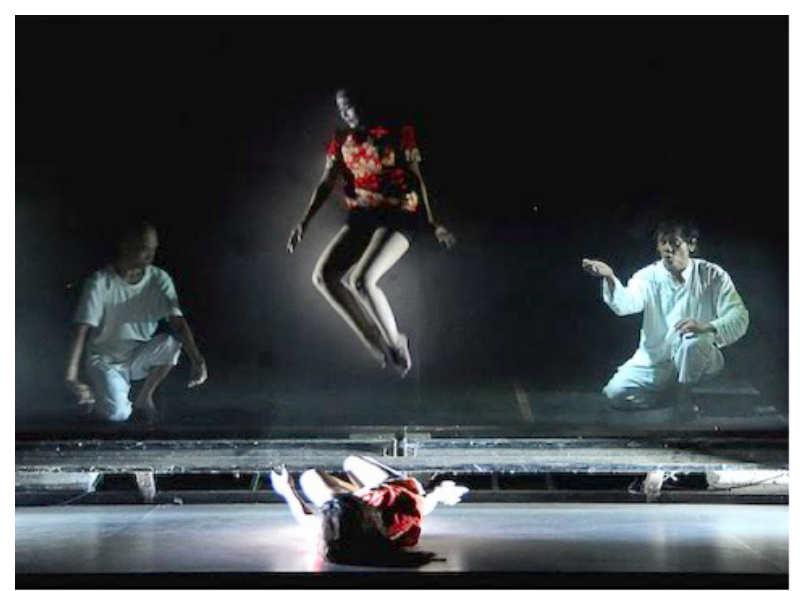

https://angkusa.wordpress.com/2017/04/30/ simulakra-realita-maya-dalam-dunia-kontemporer/

\section{DIGITALISASI GERAK KARYA HARRY NURIMAN}

Harry Nuriman seorang dosen di Fakultas Seni Rupa dan Desain ITB yang bereksperimen menggunakan teknologi untuk mendigitalisasikan gerak-gerak tari dengan menggunakan media Motion Capture. Ia melakukan penelitian-penelitian mengenai representasi dan koneksi antara tubuh dengan media baru bagaimana tubuh dapat dimodifikasi dalam konteks teknologi (Nuriman, 2018). Tubuh sebagai informasi pada dasarnya berbicara tentang digitalisasi dan moda komunikasi untuk melihat hubungan dan keterhubungan corpereality dan consciousness. Kedua aspek ini berisi tema dan isu modifikasi baik secara koseptual maupun secara praktis (Fuery, 2009).

Karya pertamanya yang sudah digagas tahun 2015 baru terealisasi tahun 2016. Ia merelasasikan programnya dengan mencoba mendigitalisasikan tari Topeng Koncaran pada bagian topeng Klana. Karyanya menggunakan teknologi motion capture (MOCAP) sebuah teknologi pembuatan film animasi dengan menggunakan perekam gerakan. la juga menggunakan multi kamera dan menggunakan marker yang dipasang pada tubuh penari (Nuriman dkk, 2018). Karya ini sudah dipatenkan pada tahun 2017. Tujuannya mengeksplorasi pemanfaatan teknologi CGI untuk menyusun sistem tanda tubuh digital 
sehingga melahirkan karya model digital dari karya seniman tersebut. Dibuatnya karya ini adalah membuat analisis bagaimana teknologi digital dan elektronik yang membentuk media baru yang telah menimbulkan akibat dan berpengaruh terhadap peran dan fungsi tubuh serta penubuhan (embodiment) seniman.

\section{Berikut foto hasil karya Harry Nuriman}
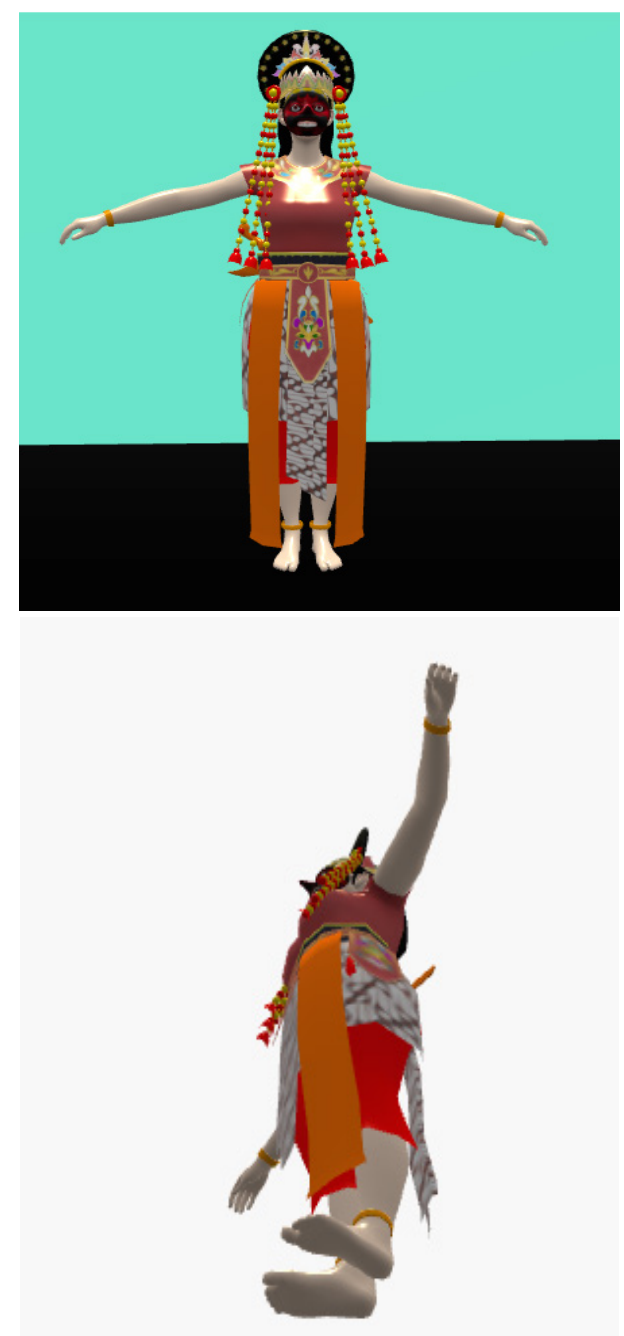

Karya Nuriman ini, hasil capture-annya muncul gambar seperti ini, gambar ini dapat dilihat dari berbagai sudut pandang. Teknik yang dilakukan sampai model ini adalah gerak tubuh seniman diaplikasikan ke dalam tubuh digital (model 3D), lengkap dengan topeng, kostum dan aksesoris, atau pendukung lainnya. Tubuh digital (model 3D) bisa dilihat dari berbagai sudut secara 360 derajat, bahkan dari sudut yang selama ini tidak pernah bisa dilihat oleh penonton dalam pertunjukan konvensional. Ornamen pada tubuh digital juga bisa dilihat secara detail dan bisa digerakkan sesuai gerak asli, dan terjaga dari kemungkinan modifikasi atau improvisasi gerakan yang bisa merusak orisinalitas dan keklasikan sebuah karya (Nuriman, wawancara, 09 Nov 2020).

Sosok dengan gerak-gerak sangat menarik, di mana gerak-gerak yang didigitalisasikan pada pengembangannya dapat menggunakan sosok atau tokoh lain pukan penari topeng yang seperti dilihat pada gambar. Contoh lain diterapkan pada laki-laki berpakaian adat Bali. Metode ini juga digunakan oleh amnimator ayang menggunakan model ini hingga viralnya, yaitu sebuah tayangan Spiderman dan tokoh-tokoh pahlawan dalam film animasi atau karun menari Jawa.

\section{PENUTUP}

Dua karya yang dijadikan model tadi tentang bagaimana tari dikawinkan dengan teknologi menjadi sangat menarik. Dua model tersebut berbeda tujuan dan sasaran tetapi paling tidak menjadi gambaran penting sebagai upaya-upaya yang dilakukan oleh para kreator untuk menghadirkan kebaruan, bahkan bisa jadi memiliki nilai jual. Harapannya kedua model yang disampaikan menjadi referensi untuk para peneliti dalam melakukan eksperimen lain. Juga dengan model-model lain atau media lain yang sekarang sedang digandrungi apakah penggunaan Virtual Reality (VR) maupun Augmented Reality (AR), yang tahun lalu sudah dilakukan oleh peneliti dari Makasar dan oleh Wanda Listiani dari ISBI Bandung.

\section{DAFTAR PUSTAKA}

Enggar Harususilo, Yohanes. https://edukasi. kompas.com/read/201811/13/16255641/

indonesia-telah kolaborasi-seni-dan-teknologi-sebelum-era-internet?page=all

Fuerey, Kelly. (2009). New Media: Culture and Image. New York, Palgrave Macmillan.

Supriyanto, Eko dkk. (2014). “Empat Koreografer Tari Kontemporer Indonesia Periode 19902008" Jurnal Panggung Vol. 24 No. 4 Desember 2014, hal: 335-350. 
Nuriman, Harry, RR. Amana Dzikrillahi, Esa Fajar Hidayat. 2018). "Gerak Digital Silat Tuo Minangkabau Melalui Pemanfaatan Teknologi Motion Capture" The Journal of Society \& Media, Unesa, 2018, Vol 2 (2), 109-120.

Internet:

https://radarjogja.jawapos.com/jogjautama/2014/08/11/usung-teknologihologram-pertama-di-dunia-tariinternasional/

https://radarjogja.jawapos.com/jogjautama/2014/08/11/usung-teknologihologram-pertama-di-dunia-tariinternasional/

https://majalah.tempo.co/read/seni/146118/ tubuh-hologram-di-pinggir-kali-bedog

https://angkusa.wordpress.com/2017/04/30/ simulakra-realita-maya-dalam-duniakontemporer/

https://www.krjogja.com/hiburan/seni-danbudaya/body-in-between-kolaborasikanunsur-dunia-nyata-dan-maya/ 